\title{
EFFECTS OF WORK ENVIRONMENT ON STAFF TRAINING TRANSFER IN GHANAIAN TECHNOLOGY UNIVERSITIES AND POLYTECHNICS
}

\author{
ROBERT APPIAH ${ }^{1}$, SIMON-PETER KAFUI AHET0 ${ }^{2 *}$
}

${ }^{1}$ Faculty of Arts, College of Humanities and Legal Studies, University of Cape Coast, Cape Coast, Ghana. ${ }^{2}$ Department of Distance Education, School of Continuing and Distance Education, College of Education, University of Ghana, Legon-Accra, Ghana. *Emails: saheto@ug.edu.gh, kafuiaheto@yahoo.com

Received: 30 November 2020, Revised and Accepted: 24 December 2020

\begin{abstract}
This study sought to determine the effect of post-training work environment on the transfer of middle-level staff competencies from 2 technical universities and 2 polytechnics in the northern sector of Ghana. The mixed study was sequential explanatory research. Respondents were drawn from the Netherlands Programme for Post-Secondary Education and Training Capacity (NPT/GHA) 45 leadership and management capacity building project for the middle-level technical universities and polytechnics staff. A 5-point Likert scale questionnaire and a semi-structured interview guide were used to gather data from respondents made up of 24 (58.5\%) academic staff and 17 (41.5\%) administrative staff totaling 41 respondents for the study. The closed-ended items were analysed using statistical product and service solutions version 19 and results reported using means and standard deviations. Open-ended items were thematically analysed to support results from the closed-ended item analysis. The results revealed that respondents found the relevance of staff training, learned new things and noticed an improvement in their competencies for their career prospects. However, the perception of the respondents pointed to the fact that there was little or no support from colleagues in transferring the competencies acquired from training. The study also revealed that respondents had low motivation to transfer training competencies. Since technical universities and polytechnics produce critical human resources for the industry, the post-training work environment was critical for staff training transfer with many implications for the management, leadership, growth and development of the institutions. The study recommended that training programmes should be aligned with the institutional vision, mission and goals. Again, resources committed to staff training should also budget for enhancements of the work environment to accommodate training transfer using modern technologies.
\end{abstract}

Keywords: Polytechnic, Post-training, Technical universities, Transfer of training, Work environment.

(C) 2021 The Authors. Published by Innovare Academic Sciences Pvt Ltd. This is an open access article under the CC BY license (https://creativecommons.org/licenses/by/4.0/). DOI: https://dx.doi.org/10.22159/ijoe.2021v9i1.40692. Journal homepage: https://innovareacademics.in/journals/index.php/ijoe

\section{INTRODUCTION}

Staff training is critical to the sustenance and governance of every modern society. Staff training has become necessary since work is increasingly becoming technologically driven and knowledge-based as critical factors in organisational planning and success. It is therefore incumbent on organisations such as educational institutions to train and track employees. The training and tracking contribute to increased work outputs through an efficient evaluation system that ensures that learned proficiencies are sustainably transferred into the fabric of organisations. The ability to convey the efforts, skills and holding up to the knowledge and competencies acquired from a training programme is referred to as training transfer (Ford \& Weissbein,1997). Therefore, in the contemporary corporate world, it is essential to capitalise and upsurge on the human resource abilities at the disposal of organisations to be on top of the competitive business chart (Hand \& Lev, 2003; StorbergWalker, 2004). Successful transfer of training is said to have occurred when employees from the training programmes competently utilise the competencies acquired from the training sessions into their daily activities within the work environment to improve upon productivity (Olsen, 1998). In most instances, transfer of training is not appropriately deployed, monitored or evaluated, hence rendering the training investment in individual employees challenging to measure, if not unprofitable. It is indisputable that the effectiveness of employee's training to a large extent depends on how the knowledge, skills, values and competencies are transferred and applied to the work environment (Salas \& Cannon-Bowers, 2001). Human resources practitioners support the notion that organisations invest more resources to train employees to increase their work proficiency (Kelloway \& Barling, 2000). Cooperate bodies invest their resources in equipping their employees through training programmes to boost their productivity level in the organisation (Cascio, 2000;
Noe, Hollenbeck, Gerhart \& Wright, 2006). Cumulatively, organisations in the United States of America (USA) commit billions of dollars to the training of employees to equip their competencies (Dolezalek, 2004). Organisational commitment to training also reflects their seriousness and quality of expectations or outputs. Dolezalek further emphasises in a modern era, training employees in an organisation is the norm for organisations across the globe due to the positive impact the organisational development. On the other hand, scholars also have advanced arguments that the financial investments of organisations committed to staff training need to be justified by increased productivity in the work environment (Cascio, 2000). To guarantee a successful transfer of training competencies, the design of training programmes must adapt to the employees working roles by filling their skills gaps to boost their working capabilities and increased productivity. Measuring of training transfer is necessary for organisation in their job performance evaluation. According to Wexley and Latham (2002), transfer is evaluated on a scale of positive, negative or zero. In view of Wexley and Latham's position when training reflects an increase in performance then positive transfer is said to have occurred. A positive point reflects the idea of training transfer. With the negative transfer, Wexley and Latham suggest that this occurs when the knowledge, skills, values and competencies from the training are not manifested at a greater expectation, hence decreasing the productivity level. For zero training transfer point, no effect would have been realised at all, meaning, knowledge, skills, values and competencies from the training diverge from the duties of the job hence, has no impact or relevance on the job activities.

When the design of a training programme does not address the effective implementation of the new skills and competencies acquired, then the training and competency transfer will become deficient and ineffective (Foxon, 1997). Additionally, for a training transfer to be relevant and acceptable, it must be 
in consonance with the organisational goals, mission and vision and the potential to reflect better job performances (Rossett, 1997; Taylor, 2001). Taylor (2001) posits that most organisations do not create the platform for employees from training programmes to exhibit their new potentials and this, therefore, renders the training programme not very useful to the organisation. Therefore, it can be concluded that the duties of an organisation are crucial in consideration of assuring positive, successful training transfer.

Tertiary institutions such as technical universities and polytechnics are organisations that primarily equip learners with various competencies and skills training. Due to the capacity building mandates of such tertiary 'training' institutions, their staff needs continuous retooling to build their capacities to enable them to transfer training within the work environment. Ghana has received much international assistance to its education sector over the years. These were received in the form of technical support and grants. The NPT/GHA 45 leadership and management capacity building project was targeted at building the capacity of the middlelevel academic and administrative staff from technical universities and polytechnics in Ghana. The specific objective was aimed at improving the management and leadership practices of the middle-level academic and administrative staff at that level of education. The project was successfully implemented as scheduled with participants drawn from 8 technical universities and 2 polytechnics participating in a series of training workshops organised by the project partners. Huge sums of financial resources and human capital were invested into the project with an explicit intent of bringing about leadership and management change into the Ghanaian Technical universities and polytechnics. Despite the number of training transfer workshops benefitted by employees of organisations like the technical universities and polytechnics in Ghana, not much studies have been conducted to identify the effects of the post-training environment on the training transfer of knowledge, skills, values, attitudes and most especially, competencies. This study, therefore, sought to find out the effect of post-training work environment on the transfer of competencies of middle-level academic and administrative staff from 2 technical universities and 2 polytechnics in the northern part of Ghana.

\section{REVIEW OF THE RELATED LITERATURE}

Transfer of training competencies within institutions It is necessary to track and measure the effect of transfer training on institutions. However, studies reveal that most training programmes do not yield the expected outcomes, and this can only change if the trainees can contribute the new competencies to the work environment (Montesino, 2002). By so doing, there the efforts from trainees to drive their organisations with the new competencies through training transfer becomes a motivation. Transfer of training as the extent to which new trainees sufficiently employ all competencies acquired from training to their work (Baldwin \& Ford, 1988; Grossman \& Salas, 2011). For transfer of training to be manifested, the trained should exhibit some appreciable level of knack within the post-training work environment (Velada \& Caetano, 2007)

Usually, not much that is learned is transferred to the work environment due to unalignment between competencies acquired and the givens of the work environment. Research has proven that only $10 \%$ of training knowledge is being transferred to the working sectors after training programmes (Baldwin \& Ford, 1988). On the other hand, Wexley and Latham (2002) elucidate that only a maximum of $40 \%$ of the learning experiences is directly applied to the working sector by the end of the training programme. They, however, further argue that this initial percentage of transfer depreciate in 6 months to $25 \%$ and then eventually, after a year, decrease to $1 \%$ (Wexley \& Latham, 2002). These later findings explain the analogy that as time passes by personnel from training programmes turn to lose the zeal to utilise the experiences gained from the training. Thus, most of the resources put into the training programmes are not fully realised because of training decay effects in the work environment. Due to this, it has become crucial for trainers, managers and participants to work collectively to improve the smooth transfer of the competencies and experiences from the training.

Research outcomes have suggested the usefulness of posttraining evaluation. For instance, in 2001, Jones, Simonetti, and Vielhaber-Hermon conducted a study to assist some people to understand the ways of managing people. The outcome revealed that the scientist involved in the training improved upon their ways of going about their duties, self-esteem, interactions, teamwork and abilities to find solutions to issues. Again, the outcome made it visible that programmes meant to boost manager's leadership skills ensured an increase in understanding of themselves while allowing them to gain more knowledge and experiences of leadership techniques. It was observed from the evaluation of the training transfer that one of the ways of determining training effectiveness is to undertake post-training evaluation sometime after trainees have returned to their workplace. The works of Yaghi and Bates (2020) and Jones, Simonetti, and Vielhaber-Hermon (2001) throw light on work environment characteristics such as support from supervisors and colleagues as necessary conditions that facilitate training transfer.

According to Bates (2003), leaders and supervisors are crucial in matters related to the successful transfer of training experiences and this is done as they apply their supervisory tactics and competencies to influence the transfer of the competencies and experiences learned by the employee. Bate's argument supports the view that training design should aim at generating post-training outcomes that are consistent with the objectives of training. Bate's appeared to suggest that training activities should bring a return on investment to the organisations who participate in the training programme. It is also believed that institutional management support, made available to employees as they commence and by the end becomes a very vital tool in influencing the learning transfer (Baldwin \& Magjuka, 1991). For training to have any effect on the trainee's work output, there is a need for positive support from institutional management.

\section{Transfer of training within the work environment}

Work environs reveal the real work conditions under which trainees are required to utilise their competencies after receiving training. There are many variables at the work environment which have influence on the training transfer. They include organisational climate, support from colleagues, subordinates and management staff of the institution. That is to say that for a successful training transfer, much emphasis relies on the environs of the working sectors (Eseryel, 2002, p. 20). Also, Eseryel further indicated that "constitutes of the posttraining environment can encourage (e.g., rewards, job aids), discourage (e.g., ridicule from colleagues), or even prevent the institution of novel competencies and experiences in the job (e.g., absence of essential paraphernalia)." Eseryel additionally indicated that there are three indicators that affect the aim to utilise the competencies from the training to their work.

Obstacles to successful transfer of training are in various forms. Broad and Newstrom (1992) identified three key obstacles to transfer of training; these are the absence of inducement, intrusion at the working environs and lack of reassuring environment for amendment. Broad and Newstrom further posited that supervisors are key personnel involved in finding solutions to the problems attached to the smooth transfer of training. In the same vein, Kotter (1990) indicated that managers have the primary responsibility for dealing with training transfer barriers using inducement. In addition, he mentioned that aside from managerial reinforcement, support and competencies acquired by employees during programmes, transfer training may not be an easy job. Broad \& Newstrom (1992) deployed that superintendents and directors themselves should acquire some level of training in order to improve their skills on how to manage the newly trained employees to use their training skills. 
Transfer of training within the work environment can sometimes be hampered by poor design. Learners from training programmes are easy to apply the new concept when provided to perform on their previous tasks. However, for some learners, their working environment turn to create some hindrances for them in relation to smooth transfer of training knowledge (Weiner, 2020). This conclusion from Weiner (2020) indicates the notion of learners from a trainee programme who turns to come back to their old duties turns to have a great chance to put into operation their newly acquired competencies to the job. Therefore, without a conducive working environment, there are limitations in the smooth transferring of training knowledge. Hence, the implication is that learners from training programmes who do not have support at their workplace might experience enormous skills decay than those who are supported (Tracey, Tannenbaum \& Kavanagh, 1995).

Furthermore, a working sector that provides an uninterrupted work learning experience stands to promote competencies that enhance communication and build up healthy work relationships, growth and development (Toquero, 2020). When there is team building in an enhanced communication sector, organisational representatives get to know more about the roles and duties of members in the sector. Cooperation and teamwork among workers and leaders of the organisations reflect facilitation in the transfer of training competencies (Tracey, Tannenbaum \& Kavanagh, 1995).

The essence of equipping and boosting the competencies and abilities of employees is crucial in this world of transforming the working environment. New employees require training programmes to enable them to perform their duties, operation technological materials, expectations and ways of going about their responsibilities in the organisation. Consequently, in most institutions, huge resources are invested into the training of workers to boost their performance levels and increase the organisation productivity level as well. (Yamnill \& McLean, 2001). Yamnill and McLean further mentioned that the employee's superintendent possesses some qualities which present some power in relation to the learner's behaviour in utilising the training experiences to their work duties. When supervisors ignore, or discourage skill use, trainees are more likely unwilling to use the competencies they have gotten in the learning process and may even lead to attrition (Franco, Silva \& Rodrigues, 2019).

Factors that affect training transfer vary. Training transfer could be classified into organisational and human factors (Lim \& Morris, 2006). Where work system factors consist of elements linked to the ways of the organisation through the means of free interactions and opposition to the modification to meet the objectives of the training and that of the organisation (Haas, 2018). Montesino (2002) indicated that people-related factors embrace encouragement from the superintendent, colleagues and role models. They further argued that without disregarding the other various factors that also stand as working environment factors influencing the transfer of training, focus on various research is based on the key responsibilities of supervisors and fellow colleagues. Aside from all the factors affecting the transfer of training, the most crucial moment to facilitate the transfer of training is a period after a training programme.

Apart from the employee who has received training for the transfer training, the organisational work environment also includes superiors and clients. Gumuseli and Ergin (2002) opined that managers and supervisors are vital representatives for training transfer and their directorial skills will be very helpful in influencing training learning transfer, which would yield a great positive productivity level. From their analyses, supervisors exert some potentials that help in the easy transfer of training knowledge and competencies. This finding proposed $t$ post-training when supported by managers can have a great impact on the training transfer process. This suggests supportive work environment at the beginning, during the course and end of the training programme have an impact on the learner's intention to get trained and transfer the new knowledge and competencies to the job environment (Richmond \& Roach, 1992). It can, therefore, be inferred from the argument of Richmond and Roach that what happens at the workplace can either enhance or discourage the desire to transfer training competencies to the workplace.

\section{SIGNIFICANCE OF THE STUDY}

The study addresses the effect of the post-training work environment of staff on the transfer of competencies within Technical universities and polytechnics in the northern sector of Ghana. This study will be beneficial to the participants and their institutions, units within the tertiary education system responsible for staff training and capacity building. Findings and recommendations will serve as a guide to managers and administrators of technical universities, polytechnics and tertiary institutions for the needed support (budget implementation strategies) to facilitate the application of the learned competencies after the training.

\section{RESEARCH QUESTIONS}

1. What are the participant's perceptions of the relevance of the capacity building training projects in meeting their training needs?

2 In what ways have the post-training work environment affected the transfer of the training competencies of participants?

\section{METHODOLOGY}

This study was mixed-method research utilising the sequential explanatory research approach (Creswell \& Plano Clark, 2017). The quantitative part of the study was followed by the qualitative study. The mixed-method approach used was used to allow the diversity of views, triangulation and to help the generalisability of findings within the institutions used (Saunders, Lewis \& Thornhill, 2012). A 5-point Likert scale questionnaire and a semi-structured interview guide were used to gather data from respondents who were made up of 24 (58.5\%) academic staff and $17(41.5 \%)$ administrative staff totaling 41 respondents for the study. The closed-ended items were analysed using statistical product and service solutions version 19 and results reported using means and standard deviations. Open-ended items were thematically analysed to support results from the closed-ended item analysis.

The population is made up of 52 middle-level academic and administrative staff from 2 technical universities and 2 polytechnics in the northern part of Ghana. The staff in the population also constitutes personnel who were part of subproject 2 and sub-project 4 of the NPT (45) leadership and management capacity-building project. The middle-level participants in this study were made up of rectors, deans, heads of academic departments and heads of administrative units. The sample for the study was a census of all 41 respondents of the target population who were at a post at the time of the study. The sample included the four institutional change coordinators of the four institutions. The institutional change coordinators were purposively sampled for the study because of their leading roles in the implementation phase of the NPT (45) project. In all, 25 academic staff and 16 administrator respondents in the study. Table 1 shows the distribution and description of the sample by institutions and their categorisation according to the job roles.

From table 1 the sample shows more academic staff 24(58.5\%) than administrative staff. This is so because, though the academic staff in this study holds administrative positions such as deans, directors and heads of department with are administrative positions but meant for academics. The polytechnics had lesser representations as compared to the technical universities. This does not in any way affect the views and representations gathered from the respondents. Table 2 illustrates the distribution of respondents based on their institution, sex and years of work experience. 
Table 1: Distribution of respondents based on institution and job category

\begin{tabular}{|l|c|c|c|}
\hline \multicolumn{1}{|c|}{ Institution } & $\begin{array}{c}\text { Academic } \\
\text { staff }\end{array}$ & $\begin{array}{c}\text { Administrative } \\
\text { staff }\end{array}$ & Total \\
\hline $\begin{array}{l}\text { Bolgatanga } \\
\text { polytechnic }\end{array}$ & $\begin{array}{c}5 \\
(12.2 \%)\end{array}$ & $\begin{array}{c}4 \\
(9.8 \%)\end{array}$ & $\begin{array}{c}9 \\
(22.0 \%)\end{array}$ \\
\hline Sunyani TU & $\begin{array}{c}8 \\
(19.5 \%)\end{array}$ & $5(12.2 \%)$ & $\begin{array}{c}13 \\
(31.7 \%)\end{array}$ \\
\hline Tamale TU & $6(14.6 \%)$ & $5(12.2 \%)$ & $\begin{array}{c}11 \\
(26.8 \%)\end{array}$ \\
\hline Wa polytechnic & $5(12.2 \%)$ & $3(7.3 \%)$ & $8(19.5 \%)$ \\
\hline Total & $24(58.5 \%)$ & $17(41.5 \%)$ & $41(100)$ \\
\hline
\end{tabular}

Source: Field data

Table 2: Distribution of respondents based on institution, sex and years of work experience

\begin{tabular}{|l|c|c|c|c|c|}
\hline \multicolumn{1}{|c|}{ Institution } & Male & Female & $\mathbf{1 - 5}$ & $\mathbf{6 - 1 0}$ & $\mathbf{1 0 +}$ \\
\hline $\begin{array}{l}\text { Bolgatanga } \\
\text { polytechnic }\end{array}$ & $\begin{array}{c}8 \\
(19.5 \%)\end{array}$ & $\begin{array}{c}1 \\
(2.4 \%)\end{array}$ & $\begin{array}{c}7 \\
(17.1 \%)\end{array}$ & $\begin{array}{c}2 \\
(4.9 \%)\end{array}$ & - \\
\hline Sunyani TU & $\begin{array}{c}12 \\
(26.3 \%)\end{array}$ & $1(2.4 \%)$ & - & $\begin{array}{c}1 \\
(2.4 \%)\end{array}$ & $\begin{array}{c}12 \\
(26.3 \%)\end{array}$ \\
\hline Tamale TU & 10 & 1 & 2 & - & 9 \\
$(24.4 \%)$ & $(2.4 \%)$ & $(4.9 \%)$ & $-26 \%)$ \\
\hline $\begin{array}{l}\text { Wa } \\
\text { polytechnic }\end{array}$ & $\begin{array}{c}8 \\
(19.5 \%)\end{array}$ & - & $\begin{array}{c}2 \\
(4.9 \%)\end{array}$ & $\begin{array}{c}5 \\
(12.2 \%)\end{array}$ & $\begin{array}{c}1 \\
(2.4 \%)\end{array}$ \\
\hline Total & 38 & 3 & 11 & 8 & 22 \\
$(92.7 \%)$ & $(7.3 \%)$ & $(26.8 \%)$ & $(19.5 \%)$ & $(53.7 \%)$ \\
\hline
\end{tabular}

Source: Field data

Table 2 represents the distribution of respondent's sex and their working years of experience. The distribution shows the male domination of administrators in the institutions in this study. In terms of work experience, more than half of the respondents from the two TU and one respondent from one of the two polytechnics had more than 10 years of working experience. Generally, respondents from the polytechnics had work experience ranging from a year to 5 years.

The study used a questionnaire that contained both closeended items and open-ended items to solicit data from respondents. It was divided into sections to capture demographic details and the two research questions of this study. In addition to the questionnaire, a semi-structured interview guide was also used to solicit details from institutional change coordinators. The interview guide was developed from details based on analyses of the questionnaire. All ethical considerations were taken care of, as adherence to ethical considerations in research is essential. The considerations include but are not limited to confidentiality, avoidance of harm to respondents, informed consent and security of the data (British Sociological Association, 2002).

\section{RESULTS AND DISCUSSION}

Participants in any training programme expect the training to meet their training needs. The results were presented with means and standard deviation for discussion. The results are shown in table 3 and it shows that respondents strongly agreed (mean $=3.63, \mathrm{SD}=0.49)$ that the training sessions were relevant to the participant's current job. This finding further emerged in the interviews with the change coordinators. For instance, one respondent reiterated that:

NPT was very useful in terms of structure respondent and contents. Looking at what the poly was going through at that time, I can say that the training was useful and time by interns of the human capacity building I can say that we really benefited a lot from the training. We thought that after training it would have been extended to benefit a lot more staff of the poly but that did not happen. One other good thing about the NPT was how it brought all then polytechnics together for them to work as a team or a unit. I must say that the implementation of the change agenda could not continue end of the project even though we were and aggressively committed to seeing its implementation that has not really happened (Participant D, Institution 4).
Another participant further explained that:

I think the project was excellently carried out; training was very relevant to the fact that participants were exposed to the different types of leadership styles at the institution. As a HOD, I got to realise that there are many ways of working with the lectures and helped me to use a different leadership style in my department (Participant C, Institution X).

\section{Table 3: Relevance of project to participant's training} needs

\begin{tabular}{|l|c|c|}
\hline \multicolumn{1}{|c|}{ Statements } & Mean & SD \\
\hline $\begin{array}{l}\text { Participants were involved in the designing of } \\
\text { training programmes }\end{array}$ & 2.61 & 0.74 \\
\hline $\begin{array}{l}\text { The objectives of the training were discussed with } \\
\text { participants }\end{array}$ & 3.22 & 0.52 \\
\hline The training workshops were relevant to my job & 3.63 & 0.49 \\
\hline Training has improved my career prospects & 3.37 & 0.58 \\
\hline I did not learn anything new in the training & 1.32 & 0.57 \\
\hline $\begin{array}{l}\text { Given the opportunity, I would have opted for } \\
\text { different training }\end{array}$ & 2.05 & 0.84 \\
\hline Overall relevance of training & 2.85 & 0.62 \\
\hline
\end{tabular}

Source: Field data, $\mathrm{N}=41$

From Table 3, the findings confirm Dolezalek's (2004) position that around the globe more resources of organisations have been drive into training programmes in recent times. Cascio (2000); Dowling, Festing \& Engle (2013) also add that due to the financial resources been driven into training it therefore becomes very crucial for organisations to have proof that their resources are useful and purposeful on the job.

On the issue of whether the learned competencies could be applied on the job (mean $=3.63, \mathrm{SD}=0.49$ ) was obtained. This means the greater part of the participants settled on the account specifying the learned competencies from the training could be applied to their job. Further reveals that respondents agreed that the training had improved their career prospects ( mean $=3.37, \mathrm{SD}=0.58$ ). This shows that most participants agreed that NPT training had improved their career prospects. The results in table 3 , however, reveal that respondents disagreed that they did not learn anything new during the NPT training. (mean $=1.32, \mathrm{SD}=0.57$ ). It also emerged from the data in table 3 that participants disagreed that they cannot reveal what they have learned in training. This implies that despite the time lapse between the terminal period of the project and the time of the study, participants could still remember what they had learnt in the NPT training. It can, therefore, be concluded that the majority of middle-level technical university and polytechnic academic staff and administrators who participated in the project accepted the training was relevant to their training requirement

The study found out participant's perceived effects of posttraining working environmental issues on the transfer of the training competencies. Means and standard deviation were calculated to present the results. Table 4 presents the results that emerged from the study.

Table 4 shows that participants were unable to share the knowledge from the training sections with my colleagues (mean 2.95, SD=0.50). The results further indicated that respondents have not been able to fully transfer what they have learned from the training to the job (mean=2.90, $\mathrm{SD}=0.66)$. This was consistent with the comment of the respondent that "...apart from those who benefited from the training, we could not transfer the training to other staff of the polytechnic due to lack of interest by top management" (Participant D, Institution 4). This supports the view that collaboration and teamwork among workers and their superintendent should be promoted then support training in order for it to become institutionalised to support training transfer (Tracey, Tannenbaum \& Kavanagh, 1995). 
Table 4: Participant's perceived post-training work environmental challenges in transferring the acquired competencies to their job

\begin{tabular}{|l|l|l|}
\hline Statements & Mean & SD \\
\hline $\begin{array}{l}\text { I did not get support from my supervisor to } \\
\text { implement what I have learned from the training }\end{array}$ & 2.49 & 0.75 \\
\hline $\begin{array}{l}\text { My colleagues did not support me to transfer the } \\
\text { training to the job }\end{array}$ & 2.05 & 0.50 \\
\hline $\begin{array}{l}\text { I do not have the requisite materials to } \\
\text { implement what I have learned }\end{array}$ & 2.29 & 0.78 \\
\hline $\begin{array}{l}\text { I have not been able to share what I have learned } \\
\text { from the training with my colleagues }\end{array}$ & 2.95 & 0.50 \\
\hline $\begin{array}{l}\text { I have not been able to transfer fully what I have } \\
\text { learned from the training to my job }\end{array}$ & 2.90 & 0.66 \\
\hline $\begin{array}{l}\text { Administrative procedure(bureaucracy) in the } \\
\text { institution does not allow for the transfer of } \\
\text { learned competencies }\end{array}$ & 2.63 & 0.80 \\
\hline $\begin{array}{l}\text { There is a lack of motivation for training transfer } \\
\text { in the institution }\end{array}$ & 2.85 & 0.76 \\
\hline Overall transfer challenges & 2.40 & 0.68 \\
\hline
\end{tabular}

Source: Field data, $\mathrm{N}=41$

Another challenge was the lack of motivation to transfer training competencies to the institution (mean=2.85, SD=.76). This implies that most respondents agreed that there exists an absence of enthusiasm in the transfer of training to the job in the institution. For instance, a respondent submitted that "I raised the issue of the need to organised training for staff who did participate in training at the academic board but the Rector did not show much commitment and when I persisted I realised it might bring some confrontation so I stopped" (Respondent B, Institution 2). These results imply that even though the institution's management exhibited high commitment to support participants from their institutions during the training, very little was done to ensure that the learned competencies were shared with other staff who did not take part in the training. This finding is further consistent with Baldwin and Ford (1988) who contended that superintendent assistance and work environment play a main role influencing the transfer of the training process. These results also confirmed Bate's (2003) that directors and superintendents are key agents of transfer by applying their directorial competencies and experiences to help and boost employee's training transfer.

Table 4 further indicates that administrative procedures (bureaucracy) in the institutions do not allow for the transfer of the learned competencies (mean $=2.63, \mathrm{SD}=0.80)$. This corroborates Eseryel (2002), who argued that "elements of the post-training environment can encourage, discourage or even prohibit the application of new skills and knowledge on the job." The finding also confirmed the belief that management interest and assistance at the beginning of the training, in the course of the training and at the end of the training mostly leads to a successful training transfer (Baldwin \& Magjuka, 1991). Nonetheless, the extent of trainee's motivation before training, during training and after training trainees does not guarantee successful learning transfer as far as the working environmental factors are still in existence. This finding is consistent with Tracey, Tannenbaum and Kavanagh (1995), who noted aspects of the post-training environs as either encouraging, discouraging, or even preventing the application of new learning on the job. However, given the responses in table 4 , it can be concluded that participants faced some challenges in the transfer of training to their institutions (mean= 2.40, $\mathrm{SD}=0.68$ ).

\section{CONCLUSION}

Based on the discussions so far, it can be concluded that in as much as staff training and retraining are essential for growth and development, transfer of training to the working setting is crucial for sustenance and competitiveness of the organisation. Also, the fact that work is progressively becoming knowledge and technology-based, it is essential that staff training and retraining investments are justified by ensuring the maximum transfer of the training competencies to the workplace. Additionally, institutional managers such as heads and registrars of technical universities and polytechnics should provide a conducive work environment that facilitates training transfer. Post-training environmental work variables such as motivation, supplying the right equipment and encouragement from directors, supervisors and colleagues play a crucial role in enhancing the transfer of training competencies. So, one of the surest ways to recoup the investment in training is to provide a work environment that promotes the transfer of training competencies.

This study has implications for educational administrators and planners, most especially in Technical universities and polytechnics. One of the implications they may consider include policy development for the sustainable transfer of training within their educational spaces. Again, the alignment of training, training needs of the institutions with the work environment so that competencies gained from training do not become redundant. Finally, periodic evaluation and assessment of transfer training of staff should be conducted to build a culture that ensures the training transfer of beneficiary staff to the general good of the institution.

Further studies should expand on this study to look at the impact of training transfer within the work environment of tertiary institutions across a larger sample. The study could cover tertiary institutions at national or regional levels.

\section{ACKNOWLEDGEMENT}

The authors acknowledge all the authorities and sources consulted during this study. Again, the invaluable contributions from participants cannot be quantified.

\section{AUTHORS CONTRIBUTIONS}

The authors jointly worked on the literature review and data analyses. In addition, the first author contributed the concept and data collection, while the second author was responsible for the final write-up of the study.

\section{CONFLICT OF INTEREST}

The authors declare that there is no conflict of interest related to this study.

\section{REFERENCES}

- $\quad$ Baldwin, T. T., \& Ford, J. K. (1988). Transfer of training: A review and directions for future research. Personnel psychology, 41(1), 63-105. doi.org/10.1111/j.17446570.1988.tb00632.x

- Baldwin, T. T., \& Magjuka, R. J. (1991). The perils of participation: Effects of choice of training on trainee motivation and learning. Personnel Psychology, 44(1), 5165. doi.org/10.1111/i.1744-6570.1991.tb00690.x

- Bates, R. (2003). Managers as transfer agents. In E. F. Holton III, \& T. T. Baldwin (Ed.), Improving learning transfer in organizations (pp. 243-270). Hoboken, New Jersey: John Wiley \& Sons.

- British Sociological Association. (2002). Statement of ethical practice for the British sociological association. British Sociological Association. Durham, UK: Author

- Broad, M. L., \& Newstrom, J. W. (1992). Transfer of training: Action-packed strategies to ensure high payoff from training investments. Reading, MA: Addison-Wesley.

- Cascio, W. F. (2000). Costing human resources: The financial impact of behavior in organizations (4th ed.). Cincinnati, Ohio: South-Western.

- Creswell, J. W., \& Clark, V. L. P. (2017). Designing and conducting mixed methods research (3rd ed.). Sage publications.

- Dolezalek, H. (2004). Industry report: Training magazine's exclusive analysis of employer-sponsored training in the United States. Training, 41(10), 1-20. 
- Dowling, P. J., Festing, M., \& Engle, A. D. Sr. (2013). International Human Resource Management (6th ed.). Andover, UK: Cengage Learning EMEA.

- Eseryel, D. (2002). Approaches to evaluation of training: Theory and practice. Journal of Educational Educational Technology and Society, 5(2), 92-98.

- $\quad$ Ford, J. K., \& Weissbein, D. A. (1997). Transfer of training: An updated review and analysis. Performance Improvement Quarterly, 10(2), 22-41. doi: 10.1111/j.1937-8327.1997.tb00047.x

- Foxon, M. J. (1997). The influence of motivation to transfer, action planning and manager Support on the transfer process. Performance Improvement Quarterly, 10(2), 42-63. doi.org/10.1111/j.19378327.1997.tb00048.x

- $\quad$ Franco, M., Silva, R., \& Rodrigues, M. (2019). Partnerships between higher education institutions and firms: The role of student's curricular internships. Industry and Higher Education, 33(3), 172-185. doi.org/10.1177/0950422218819638

- Grossman, R., \& Salas, E. (2011). The transfer of training: what really matters. International Journal of Training and Development, 15(2), 103-120. doi.org/10.1111/j.14682419.2011.00373.x

- Gumuseli, A. I., \& Ergin, B. (2002). The manager's role in enhancing the transfer of training: A Turkish case study. International Journal of Training and Development, 6(2), 80-97. doi.org/10.1111/1468-2419.00151

- Haas, E. B. (2018). When knowledge is power: Three models of change in international organizations (Vol. 22). University of California Press.

- Hand, J., \& Lev, B. (2003). Intangible assets: Values, measures, and risks. New York: Oxford University Press.

- Jones, M., Simonetti, J., \& Vielhaber-Hermon, M. (2001). Making scientists into leaders at Parke-Davis research. Education and Training, 43, 371-372.

- $\quad$ Kelloway, E. K., \& Barling, J. (2000). What we have learned about developing transformational leaders. Leadership and Organization Development Journal, 21(7), 355-362. doi.org/10.1108/01437730010377908

- Kotter, J. P. (1990). What leaders really do. Harvard Business Review, 68(3), 103-111.

- Lim, D. H., \& Morris, M. L. (2006). Influence of trainee characteristics, instructional satisfaction, and organizational climate on perceived learning and training transfer. Human Resource Development Quarterly, 17(1), 85-115. doi.org/10.1002/hrdq.1162

- Montesino, M. (2002). Strategic alignment of training, transfer-enhancing behaviours, and training usage: A post-training study. Human Resource Development Quarterly, 13(1), 89-108. doi.org/10.1002/hrdq.1015
- $\quad$ Noe, R. A., Hollenbeck, J. R., Gerhart, B., \& Wright, P. M. (2006). Human resource management: Gaining a competitive advantage (6th ed.). Boston, MA: McGraw-Hill Irwin.

- Olsen, Jr. J. H. (1998). The evaluation and enhancement of training transfer. International Journal of Training and Development, 2(1), 61-75. $\quad$ doi.org/10.1111/1468$\underline{2419.00035}$

- $\quad$ Richmond, V. P., \& Roach, D. K. (1992). Power in the classroom: Seminal studies. In V. P. Richmond \& J. C. McCroskey (Ed.), Power in the classroom: Communication, control, and concern (pp. 47-65). Hillsdale, NJ: Erlbaum.

- $\quad$ Rossett, A. (1997). It was a great class, but.... Training and Development, 51(7), 18-24.

- Salas, E., \& Canon-Bowers, J. A. (2001). The science of training: A decade of progress. Annual Review Psychology, 52(1), 471-99. doi.org/10.1146/annurev.psych.52.1.471

- $\quad$ Saunders, M., Lewis, P., \& Thornhill, A. (2012). Research methods for business students (6th Ed.). Harlow, UK: Pearson.

- $\quad$ Storgberg-Walker, J. (2004). Towards a theory of human capital transformation through human development Manchester, England: Swanson \& Associates.

- Taylor, B. (2001). The management of labour in Japanese manufacturing plants in China. International Journal of Human Resource Management, 12(4), 601-620. doi.org/10.1080/09585190122913

- Toquero, C. M. (2020). Challenges and opportunities for higher education Amid the COVID-19 pandemic: The Philippine context. Pedagogical Research, 5(4), 1-5, doi.org/10.29333/pr/7947

- $\quad$ Tracey, J., Tannenbaum, S. I., \& Kavanagh, M. J. (1995). Applying trained skills on the job: The importance of the work environment. Journal of Applied Psychology, 80(2), 239-352. doi.org/10.1037/0021-9010.80.2.239

- Velada, R., \& Caetano, A. (2007). Training transfer: The mediating role of perception of learning. Journal of European Industrial Training, 31(4), 283-296. doi.org/10.1108/03090590710746441

- Weiner, B. J. (2020). A theory of organizational readiness for change. In Handbook on Implementation Science. Cheltenham, UK: Edward Elgar Publishing.

- Wexley, K. N., \& Latham, G. P. (2002). Developing and training human resources in organizations. Englewood Cliffs, NJ: Prentice Hall.

- Yaghi, A., \& Bates, R. (2020). The role of supervisor and peer support in training transfer in institutions of higher education. International Journal of Training and Development, 24(2), 89-104. doi.org/10.1111/ijtd.12173

- Yamnill, S., \& McLean, G. N. (2001). Theories supporting transfer of training. Human Resource Development Quarterly, 12(2), 195-208. doi.org/10.1002/hrdq.7 